\title{
THE EFFECT OF COMPARISON BETWEEN SOYBEAN EXTRACT AND JICAMA EXTRACT AND DURATION OF FERMENTATION ON SOYGHURT QUALITY
}

\author{
Benika Naibaho ${ }^{1}$, Handaniel Hutagalung ${ }^{2}$, Samse Pandiangan $^{3}$ \\ Fakultas Pertanian Universitas HKBP Nommensen \\ Email: naibaho_benika@yahoo.co.id
}

\begin{abstract}
Soyghurt is a fermented soy milk product using Streptococcus thermophilus and Lactobacillus bulgaricus bacteria. Efforts to enrich drinks high in antioxidants are carried out by combining food ingredients that can function as antioxidants such as soybeans and jicama. The combination of these two food ingredients and the assistance of the fermentation process by S. thermophilus and L. bulgaricans was expected to increase antioxidant activity in soyghurt production.

This study used a completely randomized design (CRD) with 2 factors, namely: the first factor was the ratio of soybean juice and yam juice (S) which consisted of 4 treatment levels, namely: $S 0=100: 0, S 1=75: 25, S 2=50: 50, S 3=25: 75, S 40: 100$. Meanwhile for the second factor was the duration of fermentation $(\mathrm{F})$ which consisted of 3 levels of treatment, namely: F0 $=6$ hours, F1 $=8$ hours, F2 $=10$ hours. The parameters observed were total solids, total acid, organoleptic value, antioxidant activity, and total lactic acid bacteria in jicama soyghurt on the best samples.

The results showed that both treatment factors had a very significant effect $(\mathrm{P}<0.01)$ on total solids, total acid, and organoleptic tests of soyghurt. The study showed that the comparison of soybean juice and jicama juice and fermentation duration resulted a high protein content value of $9.18 \%$ and was in accordance with the SNI yoghurt protein content, namely minimum of $3.5 \%$. Antioxidant activity of yam bean soyghurt obtained an IC 50 value of $18.110 \mathrm{mg} / \mathrm{L}$ and it was a very strong antioxidant. Total lactic acid bacteria on yam soyghurt was $108 \mathrm{CFU} / \mathrm{ml}$ and it was high.

Based on this research results, it was suggested that soyghurt processing may use a combination with other types of fruits and use natural food coloring to give different flavors and increase the nutritional values of soyghurt.
\end{abstract}

Keywords: Lactobacillus Bulgaricans, Streptococcus Thermophiles, Antioxidants, Indonesia National Standard

\section{PENDAHULUAN}

\subsection{Latar Belakang}

Soyghurt merupakan produk fermentasi susu kedelai dengan menggunakan bakteri Streptococcus thermophillus dan Lactobacillus bulgaricus yang telah umum dipakai pada pembuatan yoghurt (Tamime dan Robinson, 2007). Jika biasanya yoghurt dibuat dari susu hewani, soyghurt dibuat dengan memanfaatkan susu nabati. Seiring dengan perkembangan teknologi pangan, susu nabati mulai diperkenalkan sebagai bahan alternatif pembuatan yoghurt yang nilai gizinya tidak kalah dibandingkan dengan 
yoghurt susu hewani. Salah satu tanaman yang dapat menghasilkan susu nabati adalah kedelai.

Menurut Liu, 2004 kedelai merupakan sumber protein nabati yang tidak kalah dibanding dengan sumber protein lain, baik dari segi jumlah maupun mutunya. Kedelai memiliki kadar protein yang tinggi yaitu $40 \%$. Kedelai mengandung isoflavon yang dipercaya dapat menurunkan resiko penyakit jantung dengan membantu menurunkan kadar kolesterol darah. Salah satu produk olahan kedelai adalah susu kedelai. Susu kedelai dapat digunakan sebagai alternatif pengganti susu sapi karena mengandung gizi yang hampir sama dengan harga yang lebih murah. Protein susu kedelai memiliki susunan asam amino yang hampir sama dengan susu sapi. Selain itu, susu kedelai juga mengandung lemak, karbohidrat, kalsium, fosfor, zat besi, vitamin A, B1, B2, dan isoflavon. Kandungan asam lemak tak jenuh pada susu kedelai relatif tinggi serta tidak mengandung kolesterol. Selain bisa dikonsumsi langsung, susu kedelai bisa diolah lebih lanjut dengan proses fermentasi. Fermentasi dapat menimbulkan citarasa baru dan membentuk tekstur sehingga mampu memperbaiki penerimaan produk susu kedelai.

Salah satu produk fermentasi yang dikembangkan menggunakan bahan baku susu kedelai adalah yoghurt susu kedelai, yang dikenal dengan nama soyghurt. Keuntungan yang didapatkan dari subtitusi susu kedelai, selain kandungan protein pada soyghurt menjadi tinggi harganya juga relatif murah. Soygurt biasanya akan lebih encer sehingga diperlukan bahan tambahan lain sebagai pengental, seperti susu skim. Proses pembuatan dan kultur yang digunakan dalam pembuatan soyghurt pada dasarnya sama pada pembuatan yoghurt. Akan tetapi, pada pembuatan soyghurt perlu adanya penambahan susu skim untuk memicu pertumbuhan dari $S$ thermophillus. Dalam pembuatan soyghurt, susu skim yang digunakan untuk meningkatkan total padatan bukan lemak, memperbaiki konsitensi dari viskositas serta berperan dalam pembentukan koagulan.

Bengkuang merupakan tanaman asli dari Amerika Tengah dan ditanam menggunakan benih. Bengkuang merupakan buah yang kaya akan berbagai zat gizi yang sangat penting untuk kesehatan terutama vitamin dan mineral. Pada penelitian yang dilakukan oleh Lukitaningsih, 2009 disebutkan bahwa bengkuang mengandung vitamin $\mathrm{C}$, flavonoid, dan saponin yang merupakan tabir surya alami untuk mencegah 
kulit rusak oleh radikal bebas serta bengkuang juga diduga merupakan sumber antioksidan potensial.

Usaha pengkayaan minuman tinggi antioksidan dilakukan dengan penggabungan bahan-bahan pangan yang dapat berfungsi sebagai antioksidan seperti kedelai dan bengkuang, dengan penggabungan kedua bahan pangan tersebut dan bantuan dari proses fermentasi oleh bakteri S. thermophillus dan L. bulgaricus diharapkan dapat meningkatkan aktivitas antioksidan dalam produk soyghurt. Antioksidan adalah zat yang dapat melawan pengaruh bahaya dari radikal bebas yang terbentuk sebagai hasil metabolisme oksidatif, yaitu hasil dari reaksi-reaksi kimia dan proses metabolik yang terjadi di dalam tubuh.

Pada penelitian ini dilakukan pembuatan soyghurt dengan kombinasi bengkoang dengan difermentasi oleh bakteri Lactobacillus bulgaricus dan Streptococcus thermophillus. Dengan kombinasi kedua bahan pangan ini diharapkan dapat menambahkan nilai gizi bagi produk soyghurt dengan tujuan sebagai minuman kesehatan.

Dalam rangka pemanfaatan sari kedelai dan sari bengkuang sebagai penambahan zat gizi dalam pembuatan soyghurt, maka perlu dilakukan penelitian tentang "Pengaruh Perbandingan Sari Kedelai dengan Sari Bengkuang dan Lama Fermentasi Terhadap Mutu Soyghurt".

\subsection{Tujuan Penelitian}

Penelitian ini bertujuan untuk :

1. Mengetahui adanya pengaruh kombinasi konsentrasi antara susu kedelai dan bengkuang dalam pembuatan soyghurt.

2. Mengetahui pengaruh lama fermentasi terhadap mutu soyghurt.

3. Menjadi sumber referensi bagi produsen soyghurt.

\subsection{Hipotesis Penelitian}

Hipotesis dari penelitian ini adalah :

1. Ada pengaruh konsentrasi susu kedelai terhadap mutu minuman soyghurt

2. Ada pengaruh konsentrasi bengkuang terhadap mutu minuman soyghurt

3. Ada pengaruh interaksi antara konsentrasi susu kedelai dan bengkuang terhadap mutu minuman soygurt.

\subsection{Kegunaan Penelitian}

Received, 09 ${ }^{\text {th }}$ March2020; Revised, 23 ${ }^{\text {st }}$ April 2020; Accepted, $24^{\text {nd }}$ April 2020 
Sebagai informasi yang bermanfaat untuk pembuatan soyghurt bagi semua pihak yang membutuhkan.

\section{BAHAN DAN METODE}

\section{Waktu dan Tempat Pelaksanaan}

Penelitian ini akan dilaksanakan pada bulan Februari - Maret 2017. Pelaksanaan penelitian dilakukan di Laboratorium Analisa, Teknologi Hasil Pertanian, Fakultas Pertanian Universitas HKBP Nommensen Medan dan Laboratorium Teknologi Pangan, Ilmu dan Teknologi Pangan, Fakultas Pertanian Universitas Sumatera Utara.

\section{Bahan dan Alat Penelitian}

\section{Bahan penelitian}

Bahan penelitian yang digunakan adalah susu bubuk, susu kedelai, sari bengkoang, gula, garam, dan starter yang digunakan bakteri Streptococcus thermophillus dan Lactobacillus bulgaricus.

\section{Alat yang digunakan}

Alat-alat yang digunakan dalam penelitian ini adalah pisau, panci, ember plastik, kompor, dandang, blender, kain saring, talenan, timbangan, saringan, kuali, plastik polietilen, corong, sendok goreng, incubator dan refrigerator.

\section{Metode Penelitian}

Metode penelitian terdiri dari rancangan percobaan dan metode analisis sebagai berikut :

\section{Rancangan percobaan}

Penelitian ini menggunakan Rancangan Acak Lengkap Faktorial (RALF) dengan 2 faktor yaitu :

Faktor I : Perbandingan sari kedelai dan sari bengkoang (S)yang terdiri dari 4 taraf perlakuan, yaitu :

$$
\begin{array}{ll}
S_{0}=100: 0 & S_{3}=25: 75 \\
S_{1}=75: 25 & S_{4}=0: 100 \\
S_{2}=50: 50 &
\end{array}
$$

Faktor II : Lama fermentasi (F) yang terdiri dari 3 taraf perlakuan, yaitu :

$$
\mathrm{F}_{0}=6 \mathrm{jam} \quad \mathrm{F}_{2}=10 \mathrm{jam}
$$


$\mathrm{F}_{1}=8 \mathrm{jam}$

Jadi jumlah kombinasi perlakuan yang diperoleh adalah 5 x $3=15$ kombinasi.

Banyaknya kombinasi perlakuan (Tc) adalah 5 x $3=15$, maka jumlah ulangan perlakuan (n) adalah sebagai berikut :

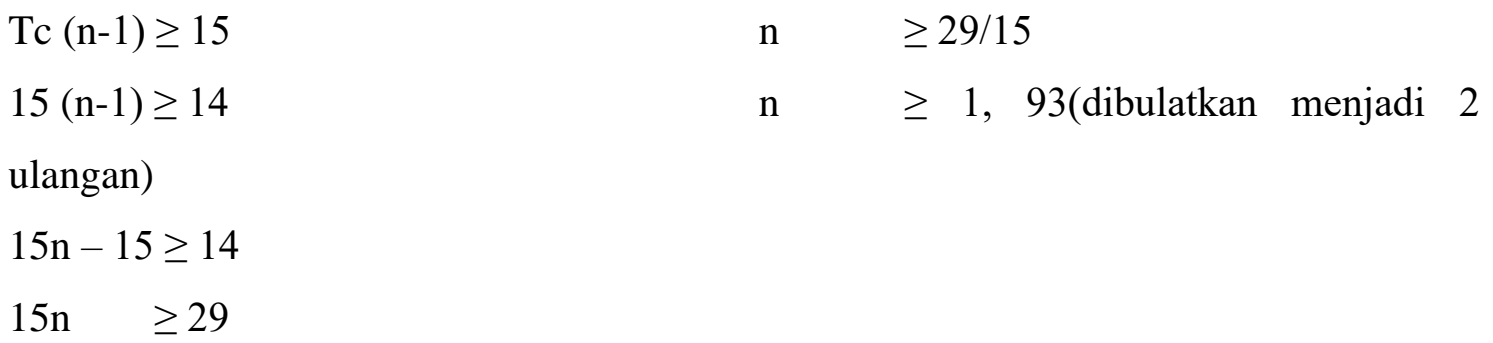

\section{Metode Analisis}

Penelitian ini dilakukan dengan model Rancangan Acak Lengkap (RAL) 2 faktorial dengan model matematik :

$$
Y i j k=\mu+\alpha i+\beta j+(\alpha \beta) i j+\varepsilon i j k
$$

Dimana :

Yijk = Hasil pengamatan pada taraf ke-i yang diberikan perlakuan faktor S dan pada taraf

ke -j yang diberikan perlakuan faktor F, pada ulangan ke-k.

$\mu \quad=$ Nilai rataan

$\alpha \mathrm{i}=$ Pengaruh dari faktor $\mathrm{S}$ pada taraf ke-i

$\beta \mathrm{j} \quad=$ Pengaruh dari faktor $\mathrm{F}$ pada taraf ke-j

$(\alpha \beta) \mathrm{ij}=$ Pengaruh interaksi dari faktor $\mathrm{S}$ pada taraf ke-i dan faktor $\mathrm{F}$ pada taraf ke-j

eijk = Galat dari faktor S pada taraf ke-i dan faktor F pada taraf ke-j dalam ulangan ke-i

\section{Pelaksanaan Penelitian}

\section{Pembuatan susu kedelai}

Biji kedelai yang digunakan harus sudah dibersihkan dari kotoran, pencucian dilakukan sampai air bilasan tampak bersih. Biji kedelai yang telah bersih kemudian direndam selama 8 jam. Air rendaman diganti setiap 2-3 jam, kemudian kedelai ditiriskan. Kedelai direbus selama 20 menit pada suhu $85-90^{\circ} \mathrm{C}$, kemudian didinginkan 
dan ditiriskan. Sediakan air panas untuk penggilingan kedelai. Perbandingan antara air dengan kedelai yaitu $1: 6$, kemudian kedelai dihaluskan dengan bantuan blender sampai menjadi bubur kedelai. Bubur kedelai yang dihasilkan kemudian disaring. Cairan yang diperoleh dari hasil penyaringan tersebut adalah susu kedelai. Simpan susu kedelai pada suhu dingin sebelum dipakai untuk perlakuan lebih lanjut. Skema pembuatan susu kedelai dapat dilihat pada Gambar 1.

\section{Pembuatan sari bengkuang}

Bengkuang yang sudah matang dan telah disortasi kemudian dikupas dan dicuci hingga bersih. Bengkuang kemudian dipotong kecil-kecil untuk mempermudah proses penggilingan. Bengkoung lalu digiling dengan bantuan blender hingga menjadi bubur. Penggilingan dilakukan dengan penambahan air dengan perbandingan 1 : 1 . Bubur hasil penggilingan kemudian disaring, hasil dari penyaringan inilah yang disebut sari bengkuang. Skema pembuatan sari kedelai dapat dilihat pada Gambar 2.

\section{Pembuatan starter}

Mikroba bibit soyghurt (starter) diperoleh dari yoghurt yang dijual dipasaran dengan mikroba yang masih hidup, yaitu yoghurt merk 'Biokul' plain. Pembuatan starterdi mulai dengan menyediakan susu bubuk $16 \%$ dan gula $2 \%$, diaduk rata dalam air mendidih. Setelah pengadukan rata tambahkan 1 sendok (5\%) Biokul plain dan diaduk hingga rata. Pindahkan ke wadah yang disiapkan, tutup rapat dengan plastik bening, beri lubang-lubang kecil pada permukaan plastik lalu lakukan inkubasi dengan suhu $40^{\circ} \mathrm{C}$ selama 6 jam. Selesai pengovenan kembali sediakan susu bubuk $16 \%$ dan gula $2 \%$, diaduk dalam air mendidih hingga larut. Kemudian tambahkan starter hasil dari inkubasi sebelumnya, lakukan pengadukan hingga merata. Setelah itu pindahkan ke wadah yang telah disediakan, tutup rapat dengan plastik bening dan beri lubang-lubang kecil pada permukaan plastik. Selanjutnya lakukan inkubasi dengan suhu $40^{\circ} \mathrm{C}$ selama 4 jam. Selesai inkubasi, tutup rapat kembali wadah dengan plastik bening kemudian simpan dalam kulkas. Skema pembuatan starter dapat dilihat pada Gambar 3.

\section{Pembuatan soyghurt}

Susu kedelai yang sebelumnya telah disterilisasi ditambahkan gula dan dicampur dengan sari bengkoang. Perbandingan antara susu kedelai dan sari bengkoang harus sesuai taraf perlakuan yang telah ditentukan. Dalam pembuatan soyghurt juga dapat ditambahkan gelatin sebanyak 0,5-1\% untuk menjaga tekstur soyghurt. Soyghurt 
kemudian didinginkan hingga suhu 43-45 ${ }^{\circ} \mathrm{C}$, inokulasikan starter campuran $L$. Bulgaricus dan S. thermophillus (1:1) sebanyak 5\% dari volume susu kedelai. Inkubasikan pada suhu kamar selama 12 jam. Hasil dari perlakuan inilah yang disebut soyghurt. Soyghurt dapat disimpan pada suhu ruang $\left(28-30{ }^{\circ} \mathrm{C}\right)$ selama tertutup dan tidak dibuka. Skema pembuatan soyghurt dapat dilihat pada Gambar 4.

\section{Pengamatan dan Pengukuran data}

Sesuai dengan perlakuan maka dilakukan pengamatan dan pengukuran data pada soyghurt dengan cara analisis terhadap parameter sebagai berikut :

\section{Total Asam (Sudarmadji, dkk., 1984)}

Sampel ditimbang sebanyak 10 gr, dimasukkan ke dalam gelas beaker dan ditambahkan aquadest sampai volume $100 \mathrm{ml}$. Diaduk hingga merata dan disaring dengan kertas saring. Diambil filtratnya sebanyak $10 \mathrm{ml}$ dan dimasukkan ke dalam erlenmayer, lalu ditambahkan phenopthalein sebanyak 2-3 tetes, kemudian dititrasi dengan menggunakan $\mathrm{NaOH}$ 0,1 N. Titrasi dihentikan setelah timbul warna merah jambu yang stabil. Perhitungan total asam dilakukan dengan rumus berikut ini :

$$
\text { Total Asam }=\frac{m l ~ N a O H}{\text { berat contoh }(\mathrm{gr}) \times 1000 \times \text { valensi asam }} \times 100 \%
$$

Keterangan : $\quad \mathrm{P}=$ Faktor pengenceran $=10$

Asam dominan = Asam laktat $\left(\mathrm{C}_{3} \mathrm{H}_{6} \mathrm{O}_{3}\right) \mathrm{BM}=90$

Valensi $=1$

\section{Total Padatan (Apriyantono dkk., 1989)}

Susu kedelai yang digunakan dalam pembuatan soyghurt memiliki total padatan sebesar 4,91\%. Total padatan sebesar 4,91\% ini diperoleh dari penambahan air pada kedelai sebanyak 6:1 pada saat penggilingan. Total padatan soyghurt merupakan gabungan komponen karbohidrat, protein, lemak, vitamin, dan mineral yang terdapat pada susu kedelai dan bahan-bahan lain yang ditambahkan.

Analisis Total Padatan Terlarut (TPT) dilakukan dengan alat hand refraktometer. Sebanyak 1 gram sampel yang sudah bersih dimasukkan dalam gelas beaker kemudian diambil satu tetes sampel dan diteteskan pada prisma refraktometer yang telah dikalibrasi dengan akuades steril. Arahkan refraktometer ke sumber cahaya. Nilai yang terbaca menunjukkan besarnya total padatan terlarut pada sampel dalam derajat satuan Brix.

Received, $09^{\text {th }}$ March2020; Revised, $23^{\text {st }}$ April 2020; Accepted, $24^{\text {nd }}$ April 2020 


\section{Uji Organoleptik (Setyaningsih et all., 2010)}

Uji organoleptik yang dilakukan adalah uji kesukaan (uji hedonik), terhadap warna, aroma, kekentalan, rasa, dan kesukaan keseluruhan. Dalam uji ini para panelis diminta mengungkapkan tanggapan pribadinya tentang kesukaan atau sebaliknya. Disamping itu panelis juga mengemukakan tingkat kesukaannya. Panelis yang digunakan adalah panelis tidak terlatih yang dipilih sebanyak 15 orang. Tingkat kesukaan dinyatakan dalam skala hedonik seperti pada Tabel 1.

Tabel 1. Skala Hedonik

\begin{tabular}{|l|c|}
\hline Skala Hedonik & Skala Numerik \\
\hline Sangat suka & 5 \\
Suka & 4 \\
Agak suka & 3 \\
Tidak suka & 2 \\
Sangat tidak suka & 1 \\
\hline
\end{tabular}

\section{Penentuan Kadar Protein (AOAC, 1984)}

Kadar protein dihitung dengan menentukan nitrogen dan dikalikan dengan faktor konversi 6,25. Kadar protein ditetapkan secara semi mikro kjeldahl. Sampel sebanyak 0,1-1,2 gram dimasukkan ke dalam labu kjeldahl $100 \mathrm{ml}$ dan ditambahkan 2gram campuran $\mathrm{K}_{2} \mathrm{SO}_{2}$ dan $\mathrm{CuSO}_{4} \cdot 5 \mathrm{H}_{2} \mathrm{O}$ (1:1) dan 2,5 ml $\mathrm{H}_{2} \mathrm{SO}_{4}$ pekat lalu didekstruksi sampai cairan berwarna hijau jernih dan dibiarkan dingin. Setelah dingin tambahkan $10 \mathrm{ml}$ aquadest dan dipidahkan ke labu suling, ditambah 8-10 ml NaOH pekat (40\%) sampai terbentuk warna coklat hitam dan segera disuling. Hasil penyulingan ditampung dengan erlenmeyer berisi $25 \mathrm{ml} 0,02 \mathrm{~N} \mathrm{H}_{2} \mathrm{SO}_{4}$ dengan 0,02 $\mathrm{N}$ $\mathrm{NaOH}$ dan juga dilakukan dengan cara yang sama untuk blanko. Kadar protein dapat dihitung dengan menggunakan rumus :

$$
\begin{aligned}
\text { Kadar protein } & =\frac{(b-c) \times N \times 0,014 \times 6,25}{a} \times 100 \% \\
\text { Keterangan : } & \mathrm{a}=\text { bobot contoh }(\text { gram }) \\
& \mathrm{b}=\text { titrasi blanko }(\mathrm{ml} \mathrm{NaOH}) \\
\mathrm{c} & =\text { titrasi sampel }(\mathrm{ml} \mathrm{NaOH}) \\
\mathrm{N} & =\text { Normalitas larutan } \mathrm{NaOH} \text { yang digunakan }
\end{aligned}
$$

\section{Total Bakteri Asam Laktat (BAL) (Fardiaz, 1989).}

Pengukuran total bakteri dilakukan pada sampel terbaik yang telah diuji parameter sebelumnya. Pengukuran total bakteri asam laktat dilakukan dengan 
menggunakan metode hitungan cawan (Total Plate Count). Metode yang digunakan yaitu dari pengenceran yang dikehendaki, sampel diambil sebanyak $1 \mathrm{ml}$ ke dalam cawan petri menggunakan pipet $1 \mathrm{ml}$. Kemudian medium MRS agar steril yang telah didinginkan sampai suhu $50^{\circ} \mathrm{C}$ dimasukkan ke dalam cawan tersebut. Selama penuangan medium, tutup cawan tidak boleh dibuka terlalu lebar untuk mengurangi kontaminasi dari luar. Segera setelah penuangan, cawan petri digerakkan di atas meja secara hati-hati untuk menyebarkan sel-sel bakteri asam laktat secara merata, yaitu digerakkan melingkar atau gerakan seperti angka 8. Setelah memadat cawan-cawan tersebut diinkubasi di dalam inkubator dengan posisi terbalik pada suhu $41^{\circ} \mathrm{C}$ selama 48 jam. Kemudian dilakukan penghitungan jumlah mikroba (CFU/ml) dengan colony counter.

\section{Aktivitas Antioksidan (Green, 2004; Gurav et al, 2007).}

Analisis aktivitas antioksidan hanya dilakukan pada sampel terbaik hasil dari uji parameter sebelumnya. Metode penentu anaktivitas antioksiadan ada bermacam cara, salah satunya adalahmetode DPPH 1,1-difenil-2-pikrilhidrazil ( $\alpha, \alpha$-difenil $\beta$ pikrilhidrazil). DPPH merupakan radikal bebas yang stabil dan tidak membentuk dimer akibat delokalisasi dari electron bebas pada seluruh molekul. Delokalisasi elektron bebas ini juga mengakibatkan terbentuknya warna ungu pada larutan DPPH, sehingga bias diukur absorbansinya pada panjang gelombang sekitar $520 \mathrm{~nm}$. Ketika larutan DPPH dicampur dengan senyawa yang dapat mendonorkan atom hidrogen, maka warna ungu dari larutan akan hilang seiring dengan tereduksinya DPPH. Semakin pudar warna yang dihasilkan, maka aktivitas antioksidannya semakin tinggi, dan juga sebaliknya.

Pengujian dilakukan dengan cara mengencerkan sampel dengan larutan methanol, dibiarkan semalaman, sampel selanjutnya diambil sebanyak $100 \mu$, diencerkan kembali dengan menggunakan $1 \mathrm{ml}$ 0,1 mM DPPH dan 4,9 ml methanol. Selanjutnya homogenisasi dengan vortex (5000 rpm), lalu disimpan di ruang gelap selama 30 menit tahap terakhir ialah peneraan absorbansi.

Analisis aktivitas antioksidan dilakukan untuk mengetahui apakah dalam soyghurt yang dihasilkan masih terkandung antioksidan, dikarenakan pada kedelai dan bengkuang banyak mengandung antioksidan. Aktivitas antioksidan dihitung dengan rumus : 


$$
\text { Aktivitas antioksidan }=1-\frac{\text { absorbansi sampel }}{\text { absorbansi kontrol }} \times 100 \%
$$

Kacang Kedelai

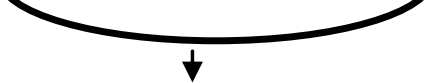

Pemanasan $90-100^{\circ} \mathrm{C}, 15$ menit,pemisahan kulit

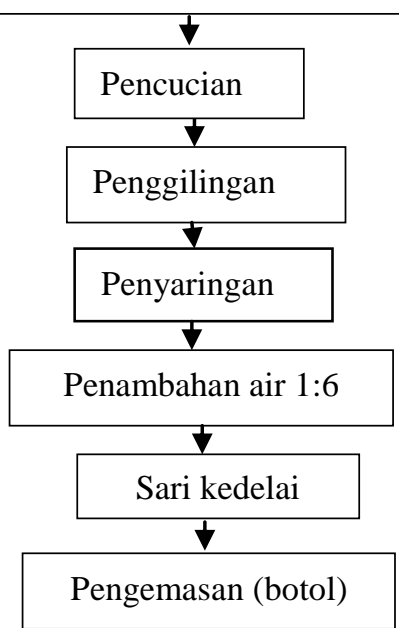

Gambar 1. Skema Pembuatan Susu Kedelai

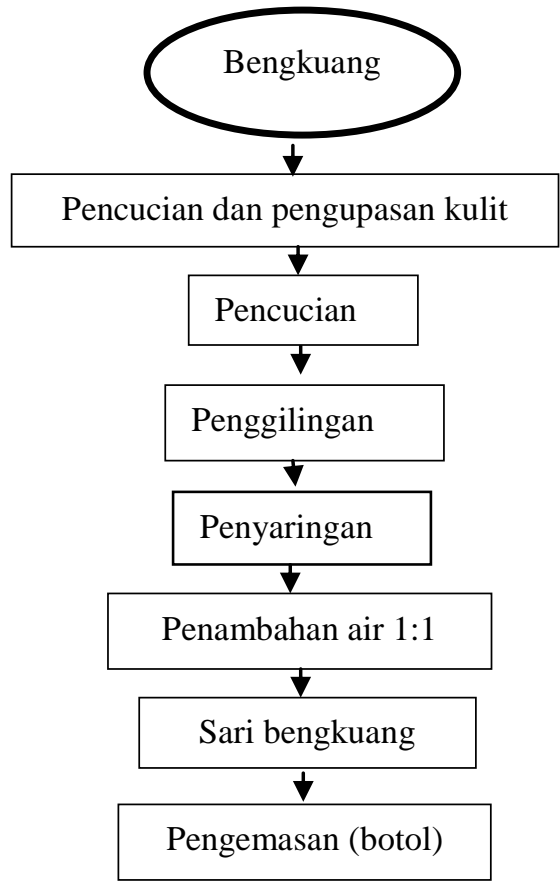

Gambar 2. Skema Pembuatan Sari Bengkuang 


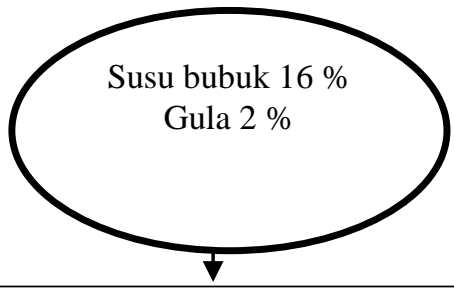

Pengadukan dalam air mendidih hingga larut

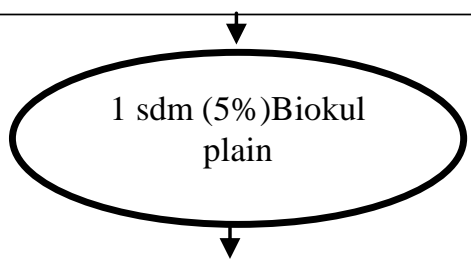

Pengadukan hingga merata

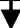

Tutup dengan plastik bening, beri lubang kecil pada permukaan plastik

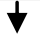

Inkubasi pada suhu $40^{\circ} \mathrm{C}$ selama 6 jam

$\downarrow$

\section{Starter 1}

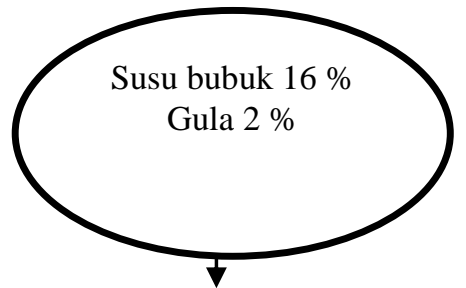

Pengadukan dalam air mendidih hingga larut

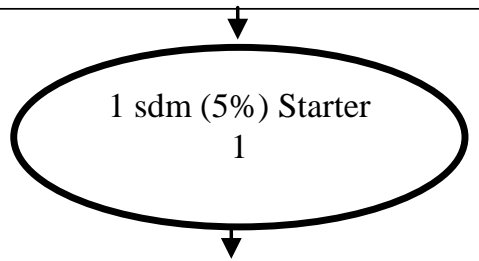

Pengadukan hingga merata

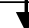

Tutup dengan plastik bening, beri lubang kecil pada permukaan plastik

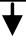

Inkubasi pada suhu $40^{\circ} \mathrm{C}$ selama 4 jam

Starter 2

Gambar 3. Skema Pembuatan Starter 


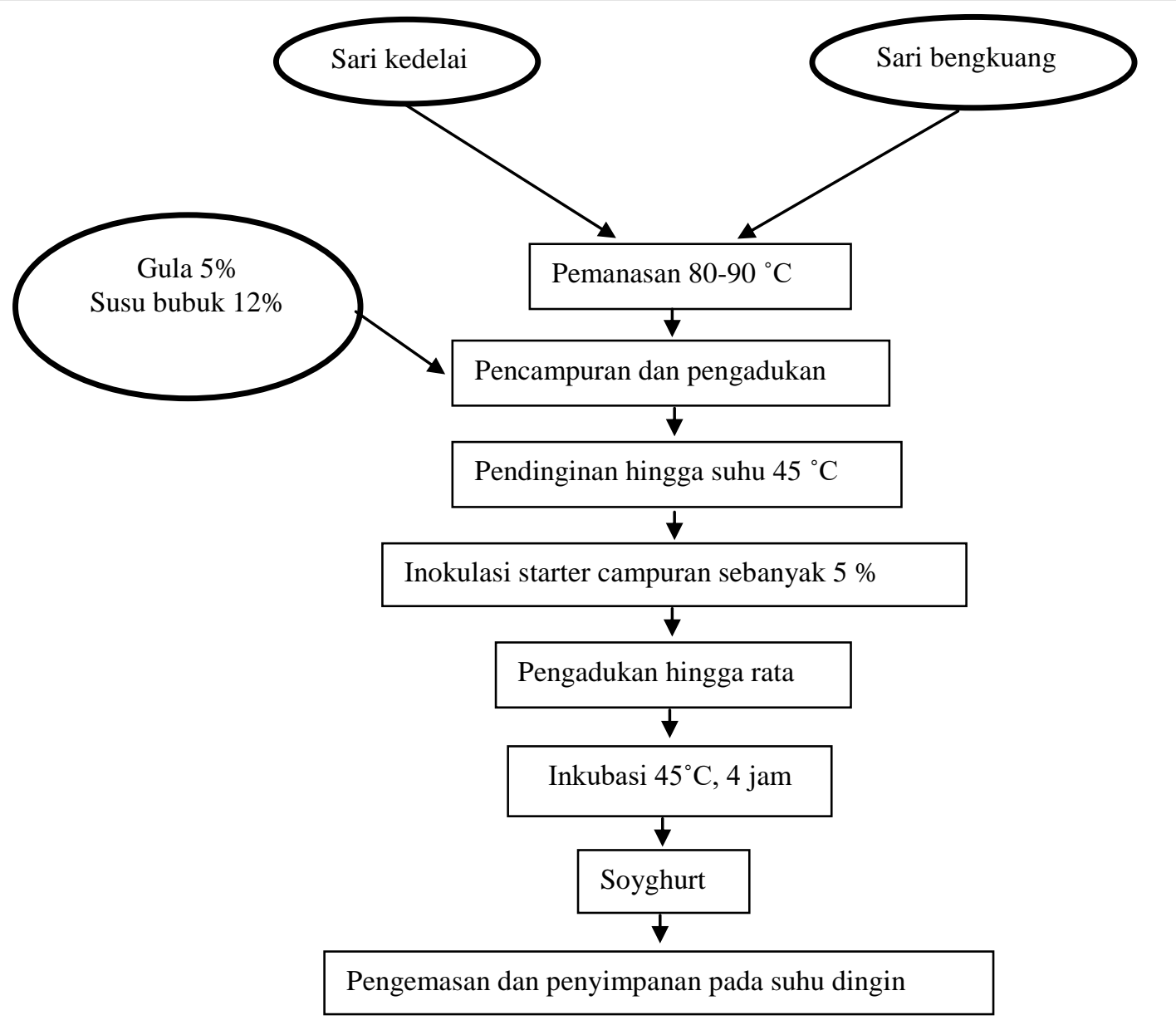

Gambar 4. Skema Pembuatan Soyghurt

\section{HASIL DAN PEMBAHASAN}

Dari hasil penelitian yang telah dilakukan dan diuji secara statistik diperoleh hasil bahwa perbandingan sari kedelai dengan sari bengkuang memberi pengaruh terhadap total padatan, total asam, dan uji organoleptik, seperti yang terlihat pada Tabel 2.

Tabel 2. Pengaruh Perbandingan Sari Kedelai Dengan Sari Bengkuang

\begin{tabular}{|c|c|c|c|}
\hline $\begin{array}{c}\text { Perbandingan } \\
\text { Sari kedelai dengan Sari } \\
\text { bengkuang }\end{array}$ & $\begin{array}{c}\text { Total } \\
\text { Padatan } \\
(\%)\end{array}$ & $\begin{array}{c}\text { Total } \\
\text { Asam } \\
(\%)\end{array}$ & $\begin{array}{c}\text { Uji } \\
\text { Organolepti } \\
\mathrm{k}\end{array}$ \\
\hline $\mathrm{S}_{0}=100: 0$ & 22.26 & 0.49 & 4.48 \\
\hline $\mathrm{S}_{1}=75: 25$ & 20.58 & 0,64 & 4.44 \\
\hline
\end{tabular}




\begin{tabular}{|l|l|l|l|}
\hline $\mathrm{S}_{2}=50: 50$ & 19.68 & 0.70 & 4.41 \\
\hline $\mathrm{S}_{3}=25: 75$ & 18.73 & 0.74 & 4.36 \\
\hline $\mathrm{S}_{4}=0: 100$ & 17.15 & 1.09 & 3.96 \\
\hline
\end{tabular}

Perlakuan lama fermentasi memberi pengaruh terhadap total padatan, total asam, dan uji organoleptik, seperti yang terlihat pada Tabel 3.

Tabel 3. Pengaruh Lama Fermentasi Terhadap Mutu Soyghurt

\begin{tabular}{|c|c|c|c|}
\hline $\begin{array}{c}\text { Lama } \\
\text { Fermentasi }\end{array}$ & $\begin{array}{c}\text { Total } \\
\text { Padatan (\%) }\end{array}$ & $\begin{array}{c}\text { Total } \\
\text { Asam } \\
(\%)\end{array}$ & $\begin{array}{c}\text { Uji } \\
\text { Organolepti } \\
\mathrm{k}\end{array}$ \\
\hline $\mathrm{F}_{0}=$ 6 Jam & 18.68 & 0.61 & 4.41 \\
\hline $\mathrm{F}_{1}=$ 8 Jam & 19.59 & 0.74 & 4.40 \\
\hline $\mathrm{F}_{2}=10 \mathrm{Jam}$ & 20.77 & 0.85 & 4.20 \\
\hline
\end{tabular}

Hasil analisa statistik dari masing-masing parameter dari setiap perlakuan dapat dilihat pada uraian berikut :

\subsection{Total Padatan}

\subsubsection{Pengaruh perbandingan sari kedelai dan sari bengkuang terhadap total padatan}

Dari daftar sidik ragam dapat dilihat bahwa perbandingan sari kedelai dan sari bengkuang memberi pengaruh sangat nyata $(\mathrm{P}<0,01)$ terhadap total padatan. Hasil pengujian LSR dapat dilihat pada Tabel 4.

Tabel 4. Pengujian LSR Efek Utama Perlakuan Perbandingan Sari Kedelai dan Sari Bengkuang terhadap Total Padatan Soyghurt

\begin{tabular}{|c|c|c|c|c|c|c|}
\hline \multirow{2}{*}{ Jarak } & \multicolumn{2}{|c|}{ LSR } & Campuran & \multirow{2}{*}{ Rataan } & \multicolumn{2}{c|}{ Notasi } \\
\cline { 2 - 4 } & $\mathbf{0 , 0 5}$ & $\mathbf{0 , 0 1}$ & Kedelai:bengkuang & & $\mathbf{0 , 0 5}$ & $\mathbf{0 , 0 1}$ \\
\hline \multirow{2}{*}{2} & - & - & $\mathrm{S}_{0}=100: 0$ & 22,26 & $\mathrm{a}$ & $\mathrm{A}$ \\
\hline 3 & 0,838 & 1,161 & $\mathrm{~S}_{1}=75: 25$ & 20,58 & $\mathrm{~b}$ & $\mathrm{~B}$ \\
\hline 4 & 0,880 & 1,217 & $\mathrm{~S}_{2}=50: 50$ & 19,68 & $\mathrm{c}$ & $\mathrm{BC}$ \\
\hline 5 & 0,905 & 1,253 & $\mathrm{~S}_{3}=25: 75$ & 18,73 & $\mathrm{~d}$ & $\mathrm{C}$ \\
\hline 5 & 0,921 & 1,275 & $\mathrm{~S}_{4}=0: 100$ & 17,15 & $\mathrm{e}$ & $\mathrm{D}$ \\
\hline
\end{tabular}


Keterangan: Notasi huruf yang berbeda menunjukkan berbeda nyata pada taraf $5 \%$ dan berbeda sangat nyata pada taraf $1 \%$.

\subsubsection{Pengaruh Lama Fermentasi terhadap total padatan}

Hasil pengujian dengan LSR dapat dilihat pada Tabel 5.

Tabel 5. Pengujian LSR Efek Utama Lama Fermentasi terhadap Total Padatan Soyghurt

\begin{tabular}{|c|c|c|c|c|c|c|}
\hline \multirow{2}{*}{ Jarak } & \multicolumn{2}{|c|}{ LSR } & Lama fermentasi & \multirow{2}{*}{ Rataan } & \multicolumn{2}{|c|}{ Notasi } \\
\cline { 2 - 4 } & $\mathbf{0 , 0 5}$ & $\mathbf{0 , 0 1}$ & $\mathbf{( \% )}$ & & $\mathbf{0 , 0 5}$ & $\mathbf{0 , 0 1}$ \\
\hline 1 & - & - & $\mathrm{F}_{0}=6$ & 18,680 & $\mathrm{c}$ & $\mathrm{C}$ \\
\hline 2 & 0,649 & 0,899 & $\mathrm{~F}_{1}=8$ & 19,597 & $\mathrm{~b}$ & $\mathrm{~B}$ \\
\hline 3 & 0,681 & 0,942 & $\mathrm{~F}_{2}=10$ & 20,771 & $\mathrm{a}$ & $\mathrm{A}$ \\
\hline
\end{tabular}

Keterangan: Notasi huruf yang berbeda menunjukkan berbeda nyata pada taraf $5 \%$ dan berbeda sangat nyata pada taraf $1 \%$.

Hubungan antara lama fermentasi dengan total padatan mengikuti persamaan garis linier positif seperti terlihat pada Gambar 5.

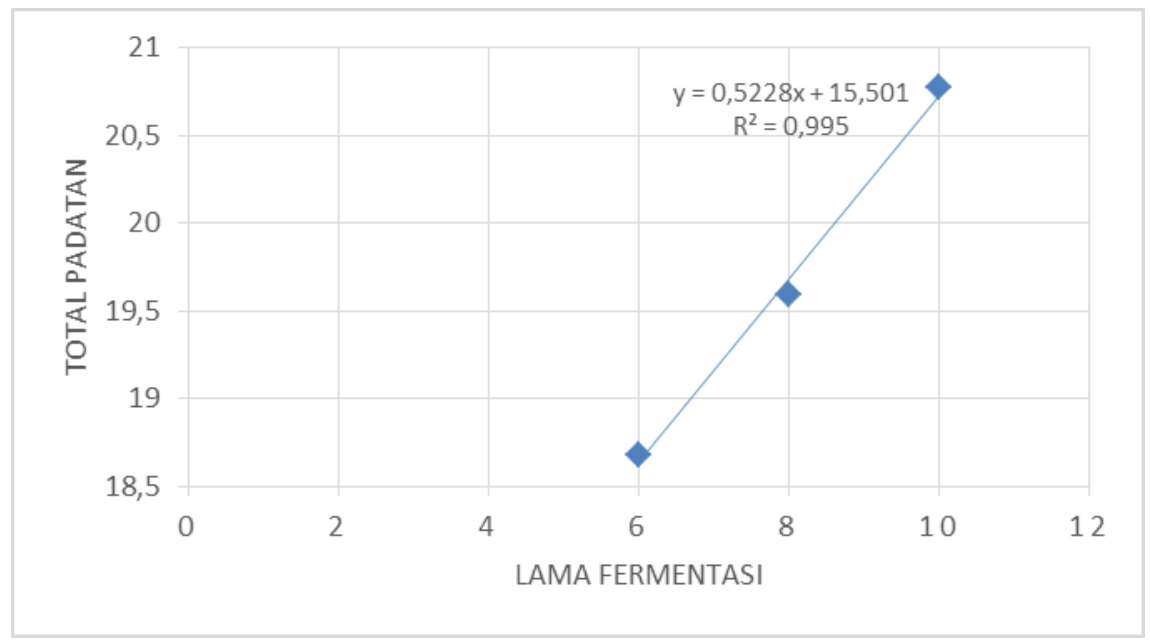

Gambar 5. Hubungan Antara Lama Fermentasi Dengan Total Padatan

\subsection{Total Asam}

\subsubsection{Pengaruh perbandingan sari kedelai dan sari bengkuang terhadap total asam}

Dari daftar sidik ragam dapat dilihat bahwa perbandingan sari kedelai dan sari bengkuang memberi pengaruh yang berbeda sangat nyata $(\mathrm{P}<0,01)$ terhadap total asam. Hasil pengujian dengan LSR dapat dilihat pada Tabel 6. 
Tabel 6. Pengujian LSR Efek Utama Perbandingan Sari Kedelai dan Sari Bengkuang terhadap Total Asam Soyghurt

\begin{tabular}{|c|c|c|c|c|c|c|}
\hline \multirow{2}{*}{ Jarak } & \multicolumn{2}{|c|}{ LSR } & Campuran & \multirow{2}{*}{ Rataan } & \multicolumn{2}{|c|}{ Notasi } \\
\cline { 2 - 4 } & $\mathbf{0 , 0 5}$ & $\mathbf{0 , 0 1}$ & Kedelai:bengkuang & & $\mathbf{0 , 0 5}$ & $\mathbf{0 , 0 1}$ \\
\hline \multirow{2}{*}{} & - & - & $\mathrm{S}_{0}=100: 0$ & 0,493 & $\mathrm{~d}$ & $\mathrm{D}$ \\
\hline 2 & 0,079 & 0,110 & $\mathrm{~S}_{1}=75: 25$ & 0,640 & $\mathrm{c}$ & $\mathrm{C}$ \\
\hline 3 & 0,083 & 0,115 & $\mathrm{~S}_{2}=50: 50$ & 0,705 & $\mathrm{bc}$ & $\mathrm{BC}$ \\
\hline 4 & 0,086 & 0,118 & $\mathrm{~S}_{3}=25: 75$ & 0,748 & $\mathrm{~b}$ & $\mathrm{~B}$ \\
\hline 5 & 0,087 & 0,121 & $\mathrm{~S}_{4}=0: 100$ & 1,097 & $\mathrm{a}$ & $\mathrm{A}$ \\
\hline
\end{tabular}

Keterangan: Notasi huruf yang berbeda menunjukkan berbeda nyata pada taraf 5\% dan berbeda sangat nyata pada taraf $1 \%$.

\subsubsection{Pengaruh lama fermentasi terhadap total asam}

Dari daftar sidik ragam dapat dilihat bahwa lama fermentasi memberi pengaruh yang berbeda sangat nyata $(\mathrm{P}<0,01)$ terhadap total asam. Hasil pengujian LSR dapat dilihat pada Tabel 7.

Tabel 7. Pengujian LSR Efek Utama Lama Fermentasi terhadap Total Asam Soyghurt

\begin{tabular}{|c|c|c|c|c|c|c|}
\hline \multirow{2}{*}{ Jarak } & \multicolumn{2}{|c|}{ LSR } & $\begin{array}{c}\text { Lama } \\
\text { Fermentasi }\end{array}$ & \multirow{2}{*}{ Rataan } & \multicolumn{2}{c|}{ Notasi } \\
\cline { 2 - 4 } & $\mathbf{0 , 0 5}$ & $\mathbf{0 , 0 1}$ & $(\%)$ & & $\mathbf{0 , 0 5}$ & $\mathbf{0 , 0 1}$ \\
\hline 1 & - & - & $\mathrm{F}_{0}=6$ & 0,61 & $\mathrm{C}$ & $\mathrm{C}$ \\
\hline 2 & 0,061 & 0,085 & $\mathrm{~F}_{1}=8$ & 0,74 & $\mathrm{~B}$ & $\mathrm{~B}$ \\
\hline 3 & 0,064 & 0,089 & $\mathrm{~F}_{2}=10$ & 0,86 & $\mathrm{~A}$ & $\mathrm{~A}$ \\
\hline
\end{tabular}

Keterangan: Notasi huruf yang berbeda menunjukkan berbeda nyata pada taraf $5 \%$ dan berbeda sangat nyata pada taraf $1 \%$.

Hubungan antara lama fermentasi dengan total asam mengikuti garis regresi linier positif seperti terlihat pada Gambar 6. 


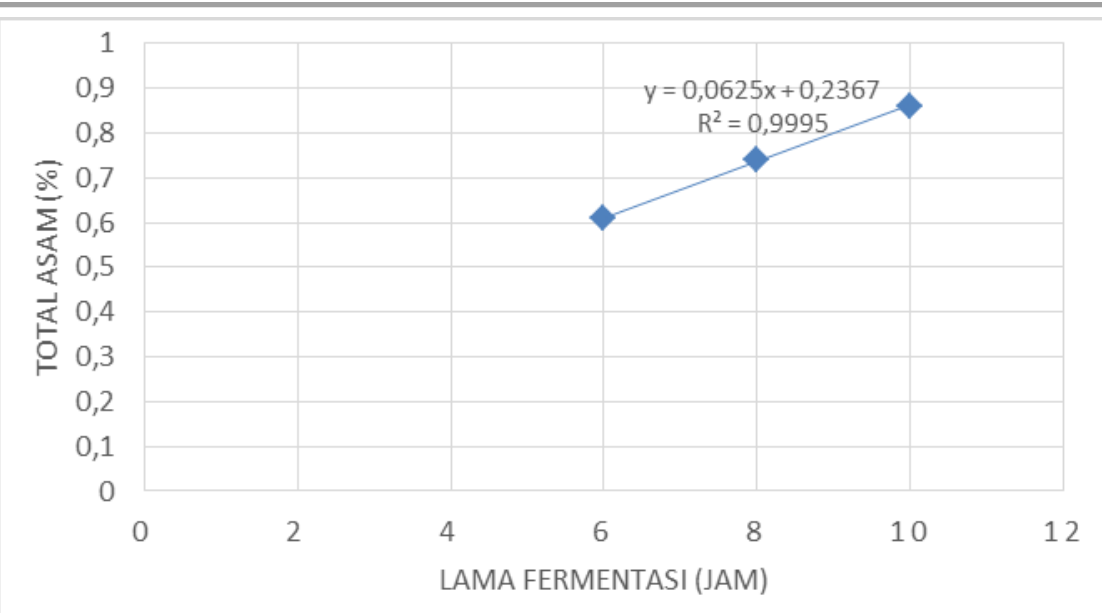

Gambar 6. Hubungan Antara Lama Fermentasi Dengan Total Asam

\subsection{Nilai Organoleptik}

1.3.1 Pengaruh perbandingan sari kedelai dan sari bengkuang terhadap nilai organoleptik

Hasil pengujian dengan LSR dapat dilihat pada Tabel 8.

Tabel 8. Pengujian LSR Efek Utama Perbandingan Sari Kedelai dan Sari

Bengkuang terhadap Nilai Organoleptik Soyghurt

\begin{tabular}{|c|c|c|c|c|c|c|}
\hline \multirow{2}{*}{ Jarak } & \multicolumn{2}{|c|}{ LSR } & \multicolumn{2}{|c|}{ Campuran } & \multirow{2}{*}{ Rataan } & \multicolumn{2}{|c|}{ Notasi } \\
\cline { 6 - 7 } & $\mathbf{0 , 0 5}$ & $\mathbf{0 , 0 1}$ & Kedelai:bengkuang & & $\mathbf{0 , 0 5}$ & $\mathbf{0 , 0 1}$ \\
\hline 1 & - & - & $\mathrm{S}_{0}=100: 0$ & 4,587 & $\mathrm{a}$ & $\mathrm{A}$ \\
\hline 2 & 0,051 & 0,071 & $\mathrm{~S}_{1}=75: 25$ & 4,517 & $\mathrm{~b}$ & $\mathrm{AB}$ \\
\hline 3 & 0,054 & 0,075 & $\mathrm{~S}_{2}=50: 50$ & 4,485 & $\mathrm{~b}$ & $\mathrm{~B}$ \\
\hline 4 & 0,056 & 0,077 & $\mathrm{~S}_{3}=25: 75$ & 4,417 & $\mathrm{c}$ & $\mathrm{B}$ \\
\hline 5 & 0,057 & 0,078 & $\mathrm{~S}_{4}=0: 100$ & 4,015 & $\mathrm{~d}$ & $\mathrm{C}$ \\
\hline
\end{tabular}

Keterangan: Notasi huruf yang berbeda menunjukkan berbeda nyata pada taraf $5 \%$ dan berbeda sangat nyata pada taraf $1 \%$.

\subsubsection{Pengaruh lama fermentasi terhadap nilai organoleptik}

Hasil pengujian dengan LSR dapat dilihat pada Tabel 9.

Tabel 9. Pengujian LSR Efek Utama Lama Fermentasi terhadap Nilai

Organoleptik Soyghurt

\begin{tabular}{|l|l|c|c|c|}
\hline Jarak & LSR & $\begin{array}{c}\text { Lama } \\
\text { fermentasi }\end{array}$ & Rataan & Notasi \\
\hline
\end{tabular}




\begin{tabular}{|c|c|c|c|c|c|c|}
\hline \hline & $\mathbf{0 , 0 5}$ & $\mathbf{0 , 0 1}$ & $\mathbf{( \% )}$ & & $\mathbf{0 , 0 5}$ & $\mathbf{0 , 0 1}$ \\
\hline 1 & - & - & $\mathrm{F}_{0}=6$ & 4,378 & $\mathrm{~B}$ & $\mathrm{~B}$ \\
\hline 2 & 0,040 & 0,055 & $\mathrm{~F}_{1}=8$ & 4,412 & $\mathrm{Ab}$ & $\mathrm{A}$ \\
\hline 3 & 0,042 & 0,058 & $\mathrm{~F}_{2}=10$ & 4,422 & $\mathrm{~A}$ & $\mathrm{~A}$ \\
\hline
\end{tabular}

Keterangan: Notasi huruf yang berbeda menunjukkan berbeda nyata pada taraf $5 \%$ dan berbeda sangat nyata pada taraf $1 \%$.

Hubungan antara lama fermentasi dengan nilai organoleptik mengikuti persamaan garis regersi linier seperti terlihat pada Gambar 7.

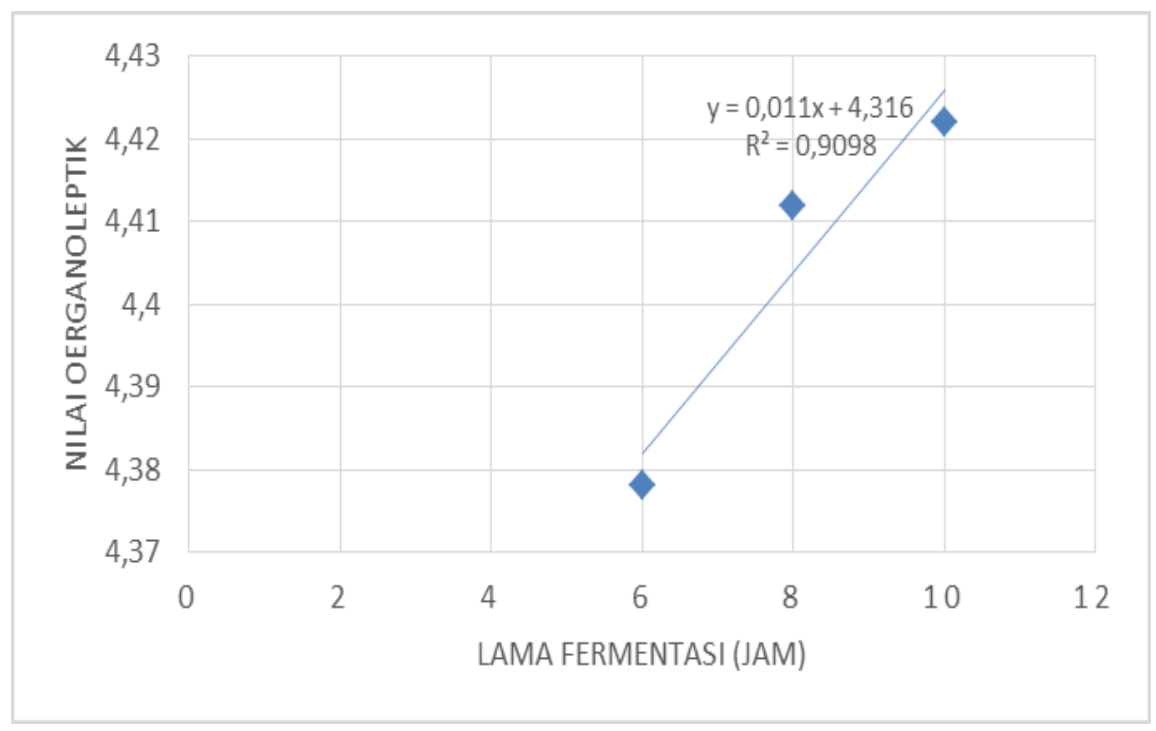

\section{Gambar 7. Hubungan Antara Lama Fermentasi Dengan Nilai Organoleptik}

\subsection{Kadar Protein}

Hasil pengamatan kadar protein soyghurt bengkuang dilakukan hanya pada sampel soyghurt terbaik yang didapat dari uji parameter yang lain. Hasil kadar protein dapat dilihat pada Tabel 10 .

Dari Tabel 10, dapat dilihat bahwa kandungan protein tertinggi diperoleh pada sampel $\mathrm{S}_{2} \mathrm{~F}_{0}$ yaitu $9,17 \%$. Sampel $\mathrm{S}_{2} \mathrm{~F}_{0}$ merupakan soyghurt dengan perbandingan sari kedelai dan sari bengkuang 50:50 dengan lama fermentasi 6 jam. Berdasarkan data dapat dilihat bahwa semakin lama fermentasi maka kadar protein yang dihasilkan semakin menurun. Hal ini disebabkan semakin lama fermentasi maka BAL akan semakin optimal untuk mengurai protein dan senyawa-senyawa lain seperti karbohidrat dan lemak. 
Tabel 10. Hasil Analisis Kadar Protein Soyghurt Bengkuang

\begin{tabular}{|c|c|}
\hline Sampel Soyghurt & Kadar Protein (\%) \\
\hline $\mathrm{S}_{2} \mathrm{~F}_{0}$ & 9,177 \\
\hline $\mathrm{S}_{2} \mathrm{~F}_{1}$ & 8,642 \\
\hline $\mathrm{S}_{3} \mathrm{~F}_{1}$ & 8,180 \\
\hline $\mathrm{S}_{3} \mathrm{~F}_{2}$ & 7,940 \\
\hline
\end{tabular}

Keterangan : Hasil rataan diperoleh dari 2 ulangan

Faktor lain yang mempengaruhi nilai kadar protein adalah kandungan bahan dasar dari soyghurt bengkuang. Tabel menunjukkan bahwa kadar protein tinggi pada perlakuan $S_{2} F_{0}$ dan $S_{2} F_{1}$. Pada $S_{2}$ perbandingan sari kedelai dengan sari bengkuang adalah 75:25, kedelai memiliki kandungan protein sekitar 34,9\% dalam $100 \mathrm{~g}$ bahan (Koswara, 1995). Hal ini menunjukkan bahwa kandungan protein dalam kedelai juga berpengaruh terhadap pada kadar protein soyghurt yang didapatkan.

\subsection{Aktivitas Antioksidan}

Hasil pengamatan aktivitas antioksidan soyghurt bengkuang dilakukan pada sampel soyghurt terbaik yang didapat dari uji parameter yang lain. Hasil uji aktivitas antioksidan dapat dilihat pada Tabel 11.

Uji potensi antioksidan soy-yamghurt didasarkan pada penangkapan radikal bebas (DPPH=1,1-difenil-2-fikrilhidrazil) oleh senyawa antioksidan melalui mekanisme donasi atom hydrogen sehingga akan dihasilkan DPPH tereduksi atau DPPH nonradikal (DPPH-H=difenil fikrilhidrazin). Parameter penentuan potensi antioksidan dapat dilihat dari nilai IC50. Nilai IC50 merupakan konsentrasi suatu larutan uji (sampel) yang memberikan peredaman DPPH sebesar $50 \%$.

Tabel 11. Hasil Analisis Aktivitas Antioksidan Soyghurt Bengkuang

\begin{tabular}{|c|c|}
\hline Sampel Soyghurt & Antioksidan IC 50 5 menit (mg/L) \\
\hline $\mathrm{S}_{2} \mathrm{~F}_{0}$ & 18,110 \\
\hline $\mathrm{S}_{2} \mathrm{~F}_{1}$ & 25,951 \\
\hline $\mathrm{S}_{3} \mathrm{~F}_{1}$ & 24,056 \\
\hline $\mathrm{S}_{3} \mathrm{~F}_{2}$ & 36,744 \\
\hline
\end{tabular}

Keterangan : IC50 $=50 \%$ peredaman DPPH selama 5 menit 
Tabel 11 menunjukkan bahwa nilai IC50 paling kuat terdapat pada perbandingan sari kedelai dengan sari bengkuang 50:50 dengan lama fermentasi 6 jam $\left(\mathrm{S}_{2} \mathrm{~F}_{0}\right)$ sebesar $18,110 \mathrm{mg} / \mathrm{L}$. Suatu senyawa dikatakan sebagai antioksidan yang sangat kuat apabila nilai IC50 kurang dari 50 ppm, aktivitas kuat apabila 50-100 ppm dan lemah bila nilai antara 150-00 ppm (Molyneux, 2004). Hal ini menunjukkan bahwa pada perlakuan $\mathrm{S}_{2} \mathrm{~F}_{0}$ memiliki aktivitas yang kuat dalam meredam radikal bebas.

Faktor lain yang mempengaruhi hasil aktivitas antioksidan pada soyghurt adalah kandungan pada sari bengkuang. Bengkuang memiliki kandungan antioksidan diantaranya vitamin C. Vitamin E, saponin, isoflavon dan flavonoid yang merupakan tabir surya alami untuk mencegah radikal bebas. Vitamin $\mathrm{C}$ menangkal radiasi dengan cara mencegah senyawa-senyawa lain agar tidak teroksidasi. Radikal vitamin $\mathrm{C}$ kemudian dihilangkan melalui reaksi dismutasi yang menghasilkan vitamin $\mathrm{C}$ dan dihidro-asam askorbat (DHAA), sehingga dapat bekerja kembali sebagai antioksidan (Almatsier, 2004).

\subsection{Total Bakteri Asam Laktat}

Hasil pengamatan Total BAL soyghurt bengkuang dilakukan pada sampel soyghurt terbaik yang didapat dari uji parameter yang lain. Hasil total BAL soyghurt bengkuang dapat dilihat pada Tabel 12.

Dari Tabel 12 dapat dilihat bahwa Total BAL terus meningkat dengan semakin lama fermentasi dari 1,55 CFU/g pada $\mathrm{S}_{2} \mathrm{~F}_{0}$ menjadi 2,59 CFU/g pada $\mathrm{S}_{3} \mathrm{~F}_{2}$.

Tabel 12. Hasil Analisis BAL Soyghurt Bengkuang

\begin{tabular}{|c|c|}
\hline Sampel Soyghurt & Total BAL $(\mathrm{CFU} / \mathrm{g})$ \\
\hline $\mathrm{S}_{2} \mathrm{~F}_{0}$ & $1,55 \times 10^{8}$ \\
\hline $\mathrm{S}_{2} \mathrm{~F}_{1}$ & $1,66 \times 10^{8}$ \\
\hline $\mathrm{S}_{3} \mathrm{~F}_{1}$ & $2,00 \times 10^{8}$ \\
\hline $\mathrm{S}_{3} \mathrm{~F}_{2}$ & $2,59 \times 10^{8}$ \\
\hline
\end{tabular}

Keterangan : Hasil rataan diperoleh dari 2 ulangan

Menurut Fuller (1992) bahwa jumlah bakteri asam laktat yang diperlukan untuk dikonsumsi dan baik untuk kesehatan adalah berkisar antara $10^{7}-10^{9}$. Berdasarkan data pada Tabel 12 menunjukkan bahwa total bakteri asam laktat mencapai $10^{8} \mathrm{CFU} / \mathrm{g}$. Jumlah total BAL yang didapatkan adalah sesuai dengan standar dari SNI (2009) yaitu 
sebesar minimal $1 \times 10^{7} \mathrm{CFU} / \mathrm{g}$. Total BAL yang didapatkan pada soyghurt bengkuang tersebut termasuk tinggi. Hal ini disebabkan L. bulgaricus dan S. thermophilus serta bakteri probiotik saling mendukung dan bersinergi dalam perbanyakan sel. Menurut Surono (1995) S. thermophilus dan L. bulgaricus saling mendukung. S. thermophiles menghasilkan asam piruvat, asam format dan $\mathrm{CO}_{2}$, serta asam folat yang menstimulir pertumbuhan L. bulgaricus. Sebagai imbalannya, L. bulgaricus akan melepas asam aminovalin, glisin dan histidin yang diperlukan oleh S. thermophiles (Prayitno, 2006). Sedangkan untuk bakteri bakteri L. acidophilus dan Bifidobacterium spp. tumbuh lambat selama proses pembuatan yogurt (Shah, 2000).

\section{KESIMPULAN DAN SARAN KESIMPULAN}

Dari hasil penelitian dapat diambil kesimpulan sebagai berikut :

1. Perbandingan sari kedelai dengan sari bengkuang memberikan pengaruh berbeda sangat nyata $(\mathrm{P}<0,01)$ pada total padatan, total asam, dan nilai organoleptik soyghurt bengkuang.

2. Perbandingan lama fermentasi memberikan pengaruh berbeda sangat nyata $(\mathrm{P}<0,01)$ pada total padatan, total asam, dan nilai organoleptik soyghurt bengkuang.

3. Soyghurt bengkuang hasil penelitian memiliki aktivitas antioksidan yang sangat kuat karena memiliki aktivitas antioksidan dengan nilai IC50 kurang dari 50 ppm.

4. Total BAL yang didapat dari hasil penelitian telah sesuai dengan SNI yaitu minimal $1 \times 10^{7} \mathrm{CFU} / \mathrm{g}$.

5. Perbandingan sari kedelai dengan sari bengkuang dan lama fermentasi mempengaruhi nilai organoleptic soyghurt bengkuang yaitu warna, rasa, aroma, kekentalan, dan kesukaan secara keseluruhan.

\subsection{SARAN}

Dari hasil penelitian dapat diberikan beberapa saran sebagai berikut:

1. Perlu dilakukan penelitian lebih lanjut dengan jenis penambahan kombinasi dengan buah lain dalam pembuatan soyghurt.

Received, $09^{\text {th }}$ March2020; Revised, $23^{\text {st }}$ April 2020; Accepted, $24^{\text {nd }}$ April 2020 
2. Perlu dilakukan penelitian terhadap lama penyimpanan dari soyghurt yang dihasilkan.

\section{DAFTAR PUSTAKA}

Almatsier, S. 2004., Prinsip Dasar Ilmu Gizi, PT. Gramedia Pustaka Umum. Jakarta Apriyanto, A., Fardiaz, D., Puspitasari, N.L., Sedarwati., dan Budijanto, S. 1989., Petunjuk Laboratorium Analisis Pangan, Direktur Jenderal Pendidikan Tinggi Pusat Antar Universitas Pangan dan Gizi. IPB. Bogor.

AOAC. 1984., "Official Method of Analysis of AOAC", $14^{\text {th }}$ Edition AOAC Inc: Arlington, Virginia.

Fardiaz, D.,dkk. 1989., “Analisa Pangan”, Departemen Pendidikan dan Kebudayaan Direktorat Jendral Tinggi Pusat Antar Universitas dan Gizi: Bogor.

Fuller, R. 1992., History and Development of Probiotik. InProbiotik the Scientific Basic, Edited by Fuller. Chapman and Hall.

Green, R. J. (2004), Antioxidant Activity of Peanut Plant Tissues. Thesis. North Caroline State University: Departement of Food Sciense, Raleigh.

Gurav, S., Deshkar. N., Gulkari. V., Duragkar. N., Patil., A. (2007)., Free Radical Scavengeng Activity of Polygala Chinensis Linn, Pharmacologyline, 2, 245-253.

Koswara, S. 1995., Teknologi Pengolahan Kedelai, Jakarta: Pustaka Sinar Harapan.

Liu, K. 2004., Fermented soy foods, In: Sinha, N.K., Y.H. Hui., E.O. Evranuz., M.Siddiq and J. Ahmed (Eds). 2011. Handbook of Vegetables and VegetableProcessing. Wiley Blackwell. USA.

Lukitaningsih, E. (2009)., The Exploration of Whitening And Sun Screening Compounds in Bengkoang Roots (Pachyrhizus Erosus).

Molyneux, P., 2004., The Use of Stable Free Radical diphenylpicrylhidraxyl (DPPH) for estimating antioxidant activity, J. Sci. Techol., 26 (2): 211-219.

Prayitno. 2006., The content of lactic acid and lactose of yoghurt fermented with different number and percentage starter bacteria, J. Anim. Product. Fakultas Peternakan Universitas Jenderal Soedirman, Purwokerto. 8 (2) : 131-136.

Setyaningsih D., Apriyantono, A., dan Sari, M. P. 2010., Analisis Sensori untuk Industri Pangan dan Agro, Bogor. IPB Press.

Received, $09^{\text {th }}$ March2020; Revised, $23^{\text {st }}$ April 2020; Accepted, $24^{\text {nd }}$ April 2020 
Shah, N. P. 2000., Probiotic bacteria: selective enumeration and survival in dairy foods, J. DairySci. 83 : 894-907.

Standar Nasional Indonesia (SNI). 2009. SNI 2981:2009., Yogurt, Badan Standarisasi Nasional (BSN), Jakarta.

Sudarmadji, S., Haryono, B., dan Suhardi.1984., "Prosedur Analisa Untuk Bahan Makanan Dan Pertanian", Angkasa: Bandung.

Surono. 1995., Indigenous fermented foods in Indonesia, Japanese J. Dairy and Food Sci. 44: A91-A98.

Tamime, A.Y. dan R.K. Robinson. 2007., Tamime and Robinson's Yoghurt Third Edition, Woodhead Publishing Limited. England. 